\title{
Impaired Cytoskeletal Integrity
}

National Cancer Institute

\section{Source}

National Cancer Institute. Impaired Cytoskeletal Integrity. NCI Thesaurus. Code C40797.

Impaired Cytoskeletal Integ rity consists of activities that interfere with, or restrain,

fabrication, construction, or maintenance of the network of protein scaffolding,

filaments, tubules, and interconnecting filamentous bridges (microfilaments,

microtubules, intermediate filaments, and associated proteins) that give shape, structure, and organization to the cytoplasm and to a cell. 